\title{
Studies on the Intestinal Absorption and Intramucosal Lipolysis of a Medium Chain Triglyceride*
}

\author{
Marc R. Playoust $\dagger$ and Kurt J. Isselbacher \\ (From the Department of Medicine, Harvard Medical School, and the Medical Services \\ [Gastrointestinal Unit], Massachusetts General Hospital, Boston, Mass.)
}

After absorption from the intestinal tract, fatty acid molecules with chain lengths of ten or less carbon atoms are known to be transported unesterified in the portal blood stream rather than in the lymph in the form of triglycerides (1-3). It has been reported that in patients with celiac disease and cystic fibrosis of the pancreas the efficiency of lipid adsorption appears to be related to the chain length of the dietary fatty acids (4, $5)$. In these subjects triglycerides of octanoic and decanoic acids (medium chain triglycerides) seem to be more completely absorbed than those containing fatty acids of higher molecular weight.

Differences in the behavior of fatty acids during absorption are probably due partly to their physical properties and partly to variations in their intramucosal metabolism. The transport of absorbed fatty acids of low molecular weight by the portal route is likely related closely to their poor incorporation into mucosal triglycerides (6). This situation may be caused by the low activity of the esterifying enzymes toward these substrates (7), the presence of an active lipase, or more likely, a combination of both factors.

Rat intestinal mucosa was examined, therefore, for the presence of an enzyme system effective in the hydrolysis of medium chain triglycerides. For these studies trioctanoin was selected as a substrate representative of this group of compounds. Active lipolysis of trioctanoin by mucosal homogenates was observed, and the intracellular localization of this lipolytic activity was studied. It was possible to demonstrate a number of properties

* Submitted for publication October 9, 1963; accepted January 2, 1964.

Supported in part by U. S. Public Health Service grant AM-03014 from the National Institutes of Health.

† Work done during tenure of a fellowship from the Postgraduate Medical Foundation, University of Sydney. Present address: Department of Medicine, University of Sydney, Australia. serving to distinguish this enzyme system from pancreatic lipase. In the rat, evidence was obtained in vivo, suggesting that unhydrolyzed trioctanoin may enter mucosal cells directly and then be subject to lipolysis by the enzyme system described.

\section{Materials and Methods}

Tripalmitin-carboxyl- $\mathrm{C}^{14}$ and trioctanoin-carboxyl-C $\mathrm{C}^{14}$ were purified by ascending chromatography on plates coated with thin layers of silicic acid; ${ }^{2}$ the developing soivent system contained by volume $40 \%$ ether, $58 \%$ hexane, and $2 \%$ glacial acetic acid. Sodium octanoate$1-C^{: 4} 1$ was converted to the free acid and also purified by thin-layer chromatography.

A mixture of medium chain triglycerides containing more than $90 \%$ trioctanoin was a gift; ${ }^{3}$ tripalmitin was obtained commercially. ${ }^{4}$ Sodium taurochoiate was synthesized from recrystallized cholic acid ${ }^{5}$ by the method of Norman (8).

Experiments with homogenates of intestinal mucosal cells. Female albino (Sprague-Dawley) rats ${ }^{6}$ weighing approximately $200 \mathrm{~g}$ were fasted overnight before use in these experiments. Each animal was killed by a blow on the head, and the small intestine was rinsed in situ with ice-cold $0.84 \% \mathrm{NaCl}$, excised, and chilled to $4^{\circ} \mathrm{C}$ in $0.278 \mathrm{M}$ mannitol in $0.01 \mathrm{M}$ sodium phosphate buffer, $\mathrm{pH}$ 7.4. The jejunal portion of the intestine was washed with fresh mannitol solution and the mucosa expressed on a glass plate. Fifteen $\mathrm{ml}$ of mannitol solution was added for each gram of expressed mucosa cells and the homogenate prepared as described previously (9). $\mathrm{Nu}$ clei and cellular debris were removed by centrifugation at $1,400 \times g$ for 10 minutes; mitochondria sedimented at $5,900 \times g$ for 15 minutes and microsomes at $105,000 \times g$ for 60 minutes. In certain experiments, indicated below, the microsomes were washed in mannitol solution and

1 New England Nuclear Corp., Boston, Mass.

2 Silica gel C (Merck). Brinkman Instruments, Great Neck, N. Y.

${ }^{3}$ Of V. Babayan, Drew Chemical Co., Boonton, N. J.

${ }^{4}$ Hormel Foundation, Austin, Minn.

5 Special enzyme grade. Mann Research Laboratories, New York, N. Y.

${ }^{6}$ Charles River Laboratories, Boston, Mass. 
sedimented again by centrifugation. Brush border fractions were prepared by the method described by Miller and Crane (10). Tissue fractions were resuspended in $0.154 \mathrm{M} \mathrm{KCl}$ in $0.01 \mathrm{M}$ sodium phosphate buffer, $\mathrm{pH} 7.4$, and their protein contents measured by the biuret reaction.

Triglyceride substrates were dissolved in a small amount of ether and homogenized in $10 \%$ crystalline bovine albumin; ${ }^{7}$ the ether was then evaporated at 35 to $40^{\circ}$ C. Crude pancreatic lipase ${ }^{8}$ was dissolved in 0.154 $\mathrm{M} \mathrm{KCl}$ containing $0.01 \mathrm{M}$ sodium phosphate, $\mathrm{pH} 7.4$.

Incubations were carried out in stoppered test tubes at $37^{\circ} \mathrm{C}$ for 10 minutes. The usual incubation mixture consisted of $1 \mathrm{ml}$ of lipid-albumin suspension, $0.3 \mathrm{ml}$ of fivefold concentrated, low calcium, Krebs-Ringer phosphate buffer, $\mathrm{pH} 7.4$ (11), $20 \mu$ moles of sodium taurocholate, and $0.5 \mathrm{ml}$ of tissue suspension or lipase solution. The final volume was $2 \mathrm{ml}$. Incubations were terminated by placing the test tubes in an alcohol-ice bath at $-15^{\circ} \mathrm{C}$ for 1 minute. After this, cold chloroform-methanol (2:1) was added. The lipids were then extracted by the method of Folch, Lees, and Sloane Stanley (12).

In experiments with tripalmitin as the radioactive substrate, the solvents containing the extracted lipids were evaporated at $40^{\circ} \mathrm{C}$ under a stream of nitrogen and the residues redissolved in chloroform. Samples were assayed for total radioactivity in a liquid scintillation spectrometer and the lipids fractionated by thin-layer chromatography as previously described (13).

In the experiments with trioctanoin as the substrate, the chloroform-methanol added at the end of the incubation contained $6 \mu$ moles of carrier trioctanoin and 42 $\mu$ moles of carrier octanoic acid, and the $\mathrm{pH}$ during the Folch extraction was adjusted to be below 3 (the $\mathrm{pK}$ of octanoic acid is 4.9). The volatility of octanoic acid made necesary a modification of the usual fractionation procedure. The fatty acids present in the lower (chloroform) phase were extracted into dilute aqueous $\mathrm{NaOH}$. To prevent the formation of emulsions the $\mathrm{NaOH}$ was saturated with $\mathrm{NaCl}$. The aqueous fraction was acidified, and the lipids were re-extracted into hexane. A suitable fraction of the hexane fraction was added directly into a counting bottle containing scintillation fluid (13) and its radioactivity determined. The neutral lipid fraction was analyzed further by thin-layer chromatography. Recovery of $\mathrm{C}^{14}$-octanoic acid after its addition to incubation mixtures containing boiled microsomes was 92 to $96 \%$. Neither evaporation of the hexane fractions derived from normal incubations nor subsequent thin-layer chromatography of the residues demonstrated significant contamination by monoglycerides or other higher glycerides.

Experiments on lipid absorption in vivo. These studies employed female rats weighing about $200 \mathrm{~g}$. Bile and pancreatic juice were excluded from the intestinal lumen by double ligation of the common bile duct at the site of its entrance into the duodenum. Twenty-four hours later, under ether anesthesia, a 20 - to $30-\mathrm{cm}$ seg-

\footnotetext{
${ }^{7}$ Nutritional Biochemical Corp., Cleveland, Ohio.
}

${ }^{8}$ Sigma Chemical Company, St. Louis, Mo. ment of lower duodenum and proximal jejunum was isolated between silk sutures, with care taken not to obstruct blood flow. The segment was washed through with $50 \mathrm{ml}$ of $0.84 \% \mathrm{NaCl}$, and the radioactive lipid, suspended in $10 \%$ albumin, was introduced in a volume of about $1 \mathrm{ml}$. After 10 minutes, a specimen of blood was withdrawn from the portal vein, the isolated segment of gut removed intact, and its contents washed out with $50 \mathrm{ml}$ of $\mathrm{NaCl}$ solution. After rapid chilling of the empty sac, a mucosal homogenate was prepared as described above using $0.154 \mathrm{M} \mathrm{KCl}$. The homogenate was then centrifuged at $900 \times g$ for 10 minutes to sediment remaining intact cells, cell debris, and nuclei. Portions of the sediment, supernatant fraction, portal vein plasma, and contents of sac lumen were extracted with chloroform-methanol and the lipids fractionated in the manner described above. The amount of radioactivity absorbed was calculated by subtracting the amount recovered in the intestinal lumen from the administered dose. Radioactive lipids in the $900 \times g$ sediment of the mucosal homogenate were considered to represent primarily adsorption on cell walls, whereas those recovered from the supernatant (cytoplasmic) fraction were regarded as intracellular (14).

\section{Results}

Hydrolysis of trioctanoin by subcellular fractions of intestinal mucosa. Table I shows that $\mathrm{C}^{14}$-trioctanoin is readily hydrolyzed upon incubation with washed microsomes from intestinal epithelial cells. In contrast, the incubation of equimolar amounts of $\mathrm{C}^{\mathbf{1 4}}$-tripalmitin with intestinal microsomes under the same conditions resulted in very little hydrolysis.

That the substrate specificity of the microsomal lipase differed from that of pancreatic lipase is apparent from the results of incubations of trioctanoin and tripalmitin in the presence of pancreatic lipase. Whereas the microsomal enzyme was predominantly active in the hydrolysis of trioctanoin, pancreatic enzyme attacked both substrates to an approximately equal extent (Table I).

Relatively little mono- or diglyceride was isolated after the microsomal hydrolysis of trioctanoin. This was probably due to the action of monoglyceride lipase, which has previously been demonstrated in intestinal cell microsomes (13). Monoglyceride lipase has a maximal activity on monoglycerides containing fatty acids with eight to twelve carbon atoms (13).

Results of studies on the intracellular localization of lipolytic activity for trioctanoin are shown 
TABLE I

Hydrolysis of trioctanoin and of tripalmitin by washed intestinal microsomes and by pancreatic lipase*



* Each incubation mixture contained $140 \mathrm{~m} \mu$ moles of either $\mathrm{C}^{14}$-trioctanoin or $\mathrm{C}^{14}$-tripalmitin, $100 \mathrm{mg}$ crystalline bovine albumin, $180 \mu$ moles $\mathrm{NaCl}, 84 \mu$ moles $\mathrm{KCl}, 30 \mu$ moles sodium phosphate, $2 \mu$ moles $\mathrm{CaCl}_{2}, 2 \mu$ moles $\mathrm{MgSO}_{4}$, and 20 $\mu$ moles sodium taurocholate in a total volume of $2 \mathrm{ml}$ and at $\mathrm{pH} 7.4$. The reaction was started by the addition either of washed intestinal microsomes (1.6 $\mathrm{mg}$ protein) or of pancreatic lipase $(0.3 \mathrm{mg}$ protein). The incubations were carried out at $37^{\circ} \mathrm{C}$ for 10 minutes and were terminated by placing the tubes in an alcohol-ice bath at $-15^{\circ} \mathrm{C}$ for 1 minute, followed by the addition of 2:1 chloroform-methanol as described in Methods. The data shown represent the mean values of three sets of experiments carried out in duplicate.

in Table II. The highest specific activity was present in the microsomal fraction, although the total activity in the soluble fraction was appreciable. At least part of the activity in the soluble fraction might have been due to contamination by pancreatic lipase, a suggestion supported by the significant hydrolysis that occurred when $\mathrm{C}^{14}$ tripalmitin was incubated with either the whole homogenate or the soluble fraction. On the other

TABLE II

Hydrolysis of trioctanoin by homogenates of rat intestinal mucosa: intracellular localization of enzyme activity*

\begin{tabular}{lccc}
\hline \multicolumn{1}{c}{ Fraction } & $\begin{array}{c}\text { Specific } \\
\text { activity }\end{array}$ & $\begin{array}{c}\text { Protein } \\
\text { in } \\
\text { fractiont }\end{array}$ & $\begin{array}{c}\text { Total } \\
\text { activity in } \\
\text { fractiont }\end{array}$ \\
\hline & $\begin{array}{c}\text { mumoles } \\
\text { falty acid } \\
\text { liberated/ } \\
\text { min/mg } \\
\text { protein }\end{array}$ & & \\
& 3.1 & 100 & \\
Whole homogenate & 1.3 & 38 & 100 \\
Nuclei (unwashed) & 3.5 & 8 & 13 \\
Mitochondria & 7.0 & 17 & 93 \\
Microsomes & 4.1 & 32 & 43 \\
Soluble fraction & & 95 & 103 \\
Sum of fractions & 0.9 & 5.6 & 2.1 \\
Isolated brush borders & & & \\
(prepared separately) & & & \\
\hline
\end{tabular}

* Each incubation was carried out for 10 minutes at $37^{\circ} \mathrm{C}$ with 15 $\mathrm{m} \mu$ moles $\mathrm{C}^{14}$-trioctanoin and 0.8 to $1.4 \mathrm{mg}$ tissue protein. See Table I for the other components of the incubation mixtures and the method of terminating the reactions.

† Figures refer to relative amounts of protein or total enzyme activity in fraction as compared to whole homogenate. All analyses were carried out in duplicate and are representative of three sets of experi ments, hand, as indicated in Table I, hydrolysis of tripalmitin by the washed microsomes was minimal.

Lipolysis of trioctanoin by isolated brush borders was slight (Table II). Furthermore, the total activity of the homogenate was not appreciably reduced by the removal of the brush border fraction.

Some properties of the microsomal trioctanoin lipase. Although extensive purification and isolation of the trioctanoin lipase from cell fractions was not carried out, characterization of some of its properties was attempted by studies with washed microsomes. It was of particular interest to compare these properties with those of pancreatic lipase.

A time study showed that the rate of hydrolysis of trioctanoin by intestinal microsomes was linear for 10 minutes. Additional experiments showed that the quantity of fatty acid liberated was roughly proportional to the amount of microsomal protein present in the incubation mixture.

Microsomal suspensions were kept for several days at 0 to $4^{\circ} \mathrm{C}$ without significant loss of activity. Freezing and thawing caused only a small loss of activity, but there was marked inhibition of activity when the microsomal preparation was immersed for 5 minutes in a water bath at $50^{\circ} \mathrm{C}$ (Table III). This contrasts with pancreatic lipase, which was stable when subjected 
TABLE III

Effect of heating on lipolytic activity of intestinal microsomes versus pancreatic lipase*

\begin{tabular}{ccc}
\hline & \multicolumn{2}{c}{ Hydrolysis of tri- } \\
octanoin by \\
$\begin{array}{c}\text { Duration } \\
\text { of heating } \\
\text { to } 50^{\circ} \mathrm{C}\end{array}$ & $\begin{array}{c}\text { Intestinal } \\
\text { microsomes }\end{array}$ & $\begin{array}{c}\text { Pancreatic } \\
\text { lipase }\end{array}$ \\
\hline minutes & \multicolumn{2}{c}{$\begin{array}{c}\text { \% of activity remaining } \\
\text { after heating }\end{array}$} \\
& 100 & 100 \\
0 & 57 & 100 \\
5 & 25 & 98 \\
10 & 22 & 84
\end{tabular}

* Incubations were carried out for 10 minutes at $37^{\circ} \mathrm{C}$ with $176 \mathrm{~m} \mu$ moles $\mathrm{C}^{14}$-trioctanoin and either intestinal cell microsomes $(0.6 \mathrm{mg}$ protein) or pancreatic lipase $(0.2 \mathrm{mg}$ protein). The microsomes and the pancreatic lipase had been immersed in a $50^{\circ} \mathrm{C}$ water bath for the time indicated. See Table I for other constituents of the incubation mixtures and the method of terminating the reaction. The data are representative of three separate experiments carried out in duplicate.

to this temperature for 5 minutes. Also, the intestinal cell lipase was inhibited by fluoride ions and by $p$-chloromercuribenzoate (PCMB) to a greater extent than pancreatic lipase (Table IV).

$\mathrm{A} \mathrm{pH}$ activity curve demonstrated that lipolysis of trioctanoin by intestinal microsomes was active over a wide $\mathrm{pH}$ range, the maximal hydrolysis occurring between $\mathrm{pH} 5.8$ and 6.3 (Figure $1)$. With the same substrate and the same experimental conditions, the $\mathrm{pH}$ activity curve for pancreatic lipase showed a very broad $\mathrm{pH}$ optimum between 6.3 and 8.2 (Figure 1).

Absorption of $C^{14}$-trioctanoin by the rat, in vivo. When $\mathrm{C}^{14}$-trioctanoin was introduced into

TABLE IV

Effect of potassium fluoride and p-chloromercuribenzoate $(P C M B)$ on trioctanoin hydrolysis*

\begin{tabular}{lccc}
\hline \hline Addition & $\begin{array}{c}\text { Concen- } \\
\text { tration of } \\
\text { inhibitor }\end{array}$ & $\begin{array}{c}\text { Hydrolysis } \\
\text { by intes- } \\
\text { tinal } \\
\text { microsomes }\end{array}$ & $\begin{array}{c}\text { Hydrolysis } \\
\text { by pan- } \\
\text { creatic } \\
\text { lipase }\end{array}$ \\
\hline moles & $\begin{array}{c}\% \text { of } \\
\text { control }\end{array}$ & $\begin{array}{c}\% \text { of } \\
\text { control }\end{array}$ \\
KF & 0 & 100 & 100 \\
$\mathrm{KF}$ & 0.02 & 12 & 87 \\
$\mathrm{PCMB}$ & 0.2 & 2 & 35 \\
& $10^{-4}$ & 29 & 100
\end{tabular}

${ }^{*}$ Incubations were carried out for 10 minutes at $37^{\circ} \mathrm{C}$ with $170 \mathrm{~m} \mu$ moles $\mathrm{C}^{14}$-trioctanoin and either intestinal microsomes $(0.6 \mathrm{mg}$ protein) or pancreatic lipase $(0.2 \mathrm{mg}$ protein). $\mathrm{KF}$ or PCMB was present in the concentrations indicated. See Table I for the other constituents of the incubation mixtures and the method of terminating the reaction. The data shown are the mean values of three separate sets of experiments.

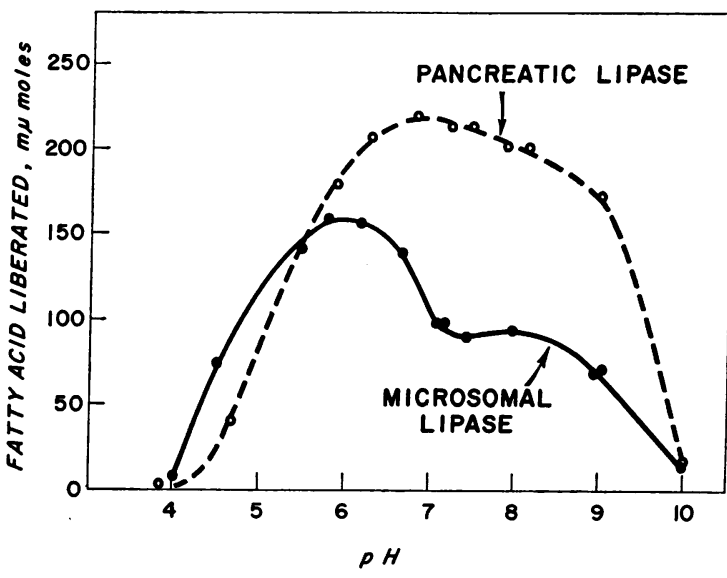

Fig. 1. EFFECT OF PH ON HYDROLYSIS OF TRIOCTANOIN BY MICROSOMAL VERSUS PANCREATIC LIPASE. Each incubation mixture contained $160 \mathrm{~m} \mu$ moles $\mathrm{C}^{14}$-trioctanoin, $1.1 \mathrm{mg}$ microsomal protein or $0.12 \mathrm{mg}$ pancreatic lipase, $10 \mathrm{mg}$ albumin, and one of the following buffers: 40 $\mu$ moles succinate $(\mathrm{pH} 4.1$ to 5.6$), 25 \mu$ moles phosphate ( $\mathrm{pH} 5.8$ to 7.4 ), $60 \mu$ moles Tris ( $\mathrm{pH} 7.7$ to 8.8 ), and 40 $\mu$ moles carbonate-bicarbonate $(\mathrm{pH} 8.9$ to 10.1$)$. Other components of the incubation mixtures and the conditions of incubation were the same as described in Table I.

an isolated loop of small intestine of an anesthetized rat, $58 \%$ of the administered lipid was absorbed during a 10-minute period. A typical result of three separate experiments is shown in Table V. Analysis of the lipid in the lumen at the end of the experiment showed that the radioactive label was still in triglyceride ( $>99 \%$ ). This confirmed the satisfactory exclusion of lipase activity from the lumen and suggested that the nature of the lipid presented to the mucosal cells for absorption was predominantly triglyceride.

A homogenate was prepared from the mucosa of the isolated sac of small intestine, and after sedimentation of cell walls, debris, and nuclei, the intracellular (cytoplasmic) lipids were extracted and analyzed for radioactivity. In contrast to the composition of the lipid in the lumen, $10 \%$ of the label in the intracellular lipids was in free fatty acids and $90 \%$ in the neutral lipid. The distribution of radioactivity was even more striking in the lipids of the portal vein plasma, where $80 \%$ of the label was in free fatty acids.

These data suggested that trioctanoin molecules entered the mucosal cells without prior hydrolysis in the lumen. Furthermore, to explain the presence of radioactive label in the fatty acid fractions 
TABLE V

Absorption of trioctanoin, octanoic acid, and tripalmitin by rat intestine, in vivo*

\begin{tabular}{|c|c|c|c|c|c|c|}
\hline \multirow[b]{2}{*}{$\begin{array}{c}\text { Substrate } \\
\text { administered } \dagger\end{array}$} & \multirow[b]{2}{*}{$\begin{array}{c}\text { Cli-lipid } \\
\text { absorbed in }\end{array}$} & \multirow{2}{*}{$\begin{array}{l}\text { Composition } \\
\text { luminal lipid } \\
\text { at end of } \\
\text { experiment } \ddagger\end{array}$} & \multicolumn{2}{|c|}{$\begin{array}{l}\text { Intracellular C14-lipid } \\
\text { recovered from mucosa } \\
\text { of intestinal sac } 8\end{array}$} & \multicolumn{2}{|c|}{$\begin{array}{l}\text { C14-lipid in portal } \\
\text { vein plasma }\end{array}$} \\
\hline & & & $\begin{array}{l}\text { Fatty } \\
\text { acid }\end{array}$ & $\begin{array}{l}\text { Neutral } \\
\text { lipid }\end{array}$ & $\begin{array}{l}\text { Fatty } \\
\text { acid }\end{array}$ & $\begin{array}{c}\text { Neutral } \\
\text { lipid }\end{array}$ \\
\hline & $\begin{array}{l}\text { \% of ad- } \\
\text { minislered } \\
\text { dose }\end{array}$ & & \multicolumn{2}{|c|}{$c p m$} & \multicolumn{2}{|c|}{$c p m / m l$ plasma } \\
\hline $\begin{array}{c}\text { C14-Trioctanoin, }^{100 \mu \text { moles }} \\
100 \mu 10^{6} \mathrm{cpm}\end{array}$ & 58 & $\begin{array}{l}>99 \% \\
\text { triglyceride }\end{array}$ & 500 & 4,000 & 600 & 100 \\
\hline $\begin{array}{c}\text { C14-octanoic acid, } \\
2.5 \mu \text { moles } \\
5 \times 10^{6} \mathrm{cpm}\end{array}$ & 71 & $\begin{array}{c}>99 \% \\
\text { fatty acid }\end{array}$ & 31,400 & 6,500 & 7,900 & 200 \\
\hline $\begin{array}{l}\text { C14-tripalmitin, } \\
15 \mu \text { moles, } \\
3.5 \times 10^{6} \mathrm{cpm}\end{array}$ & 6 & $\begin{array}{l}>99 \% \\
\text { triglyceride }\end{array}$ & $<50$ & 390 & 0 & 0 \\
\hline
\end{tabular}

* Bile and pancreatic enzymes were excluded from the intestine by bile duct ligation. Twenty-four hours later the 1 adioactive lipid was introduced into a $20-$ to $30-\mathrm{cm}$ segment of small intestine. After 10 minutes portal vein blood was sampled, the gut sac excised and emptied, and a mucosal cell homogenate prepared. For further details see Methods. $\dagger$ Lipid substrate was suspended in $1 \mathrm{ml} 10 \%$ crystalline bovine albumin.

$\ddagger \mathrm{C}^{14}$-lipid absorbed was calculated by subtracting the amount of radioactivity recovered in the sac lumen from the administered dose.

$\$$ Intracellular $\mathrm{C}^{14}$-lipid is the supernatant fraction remaining after sedimentation of intact cells, cell debris, and nuclei at $900 \times g$ for 10 minutes.

of the mucosal homogenate and the portal vein, hydrolysis of the trioctanoin evidently must have occurred within the mucosal cells.

It could be argued that these findings might be explained by the liberation of free fatty acid in the intestinal lumen, followed by its very rapid absorption and subsequent re-esterification within the mucosal cells or removal as unesterified fatty acid in the portal blood stream. Were this the correct mechanism one would expect that, if labeled octanoic acid were introduced into an isolated loop of small intestine, the distribution of radioactive lipids in the mucosal homogenate should be similar to that obtained with trioctanoin. A study with $\mathrm{C}^{14}$-octanoic acid rather than $\mathrm{C}^{14}$-trioctanoin was therefore performed. A tracer dose of $\mathrm{C}^{\mathbf{1 4}}$-octanoic acid was used to exclude the possibility of overloading the mucosal esterification mechanism. As shown in Table V, the analysis of the lipid in the intestinal mucosa revealed $80 \%$ of the label still in the fatty acid fraction; this is in contrast to the results obtained during the absorption of $\mathrm{C}^{14}$-trioctanoin, when only $10 \%$ of the radioactivity was found in the fatty acid and $90 \%$ in the neutral lipid.
The absorption of trioctanoin was compared with the behavior of a long chain triglyceride under the same in vivo conditions. $\mathrm{C}^{14}$-tripalmitin was introduced into a segment of rat small intestine. Only $6 \%$ was absorbed in 10 minutes, whereas $58 \%$ of a considerably larger quantity of trioctanoin had been absorbed in the same time interval. Furthermore, in the tripalmitin experiment very few counts were found in the intramucosal lipids and none in the lipids of the portal vein plasma.

\section{Discussion}

It seems well established that the chain length of a fatty acid influences in some manner the route of its absorption from the intestinal tract (i.e., portal versus lymphatic system) and also whether it leaves the mucosal cell in the form of triglyceride or fatty acid. Bloom, Chaikoff, and Reinhardt showed that when $\mathrm{C}^{14}$-palmitic acid was absorbed from the intestine of rats, $92 \%$ could be recovered in the lymph, whereas the recoveries in lymph of labeled myristic and decanoic acids were only 15 to $55 \%$ and $13 \%$, respectively (1). In experiments in two healthy dogs (15) 
we have found that less than $3 \%$ of orally administered $\mathrm{C}^{14}$-trioctanoin appeared in the drainage from surgical lymph fistulas; the small amount of label that was present in the lymph was in the form of triglyceride. The chemical nature of the absorbed lipid transported in the portal vein has been studied by Borgström (3). He fed $\mathrm{C}^{14}$-decanoic acid to rats and demonstrated that the radioactive label in the portal plasma was almost completely in the unesterified fatty acid fraction. Studies in a patient with chyluria (16) and in a child with chylothorax (17) indicate that the route of absorption in man appears to be the same as in animals.

Since in normal circumstances most dietary triglyceride is digested to readily absorbable fatty acid and monoglyceride, the nature of the lipid mixture presented to the mucosal cell is probably the same in all instances, regardless of the chain lengths of the fatty acids present. It follows that the subsequent partition between the medium and long chain fatty acids must be due to differences in their metabolism or behavior within the intestinal wall. Re-esterification of the long chain fatty acids appears to be a very active process (7), and the concentration of free fatty acids in the mucosal cells is always low. The transport of the triglycerides out of the cells is presumably dependent on their close association with cell membrane structures (18) leading to the formation of chylomicrons. Their appearance in the lymph and their complete absence from portal blood may be due to the inability of triglycerides to diffuse across the endothelial cells of the intestinal capillaries.

The fate of the fatty acids of shorter chain length, such as octanoic acid, might be expected to be determined by the balance between esterification and lipolysis. If a significant concentration of the octanoic acid is maintained, its physical properties (19) are such that it can readily diffuse out of the mucosal cells and through the endothelium into the blood stream. Since the rate of portal flow is so much greater than lymph flow, even a limited release of unesterified fatty acids from mucosal cells would favor the blood as the major route of absorption. Possible factors tending to keep the medium chain fatty acids in the free, unesterified form are 1) a low activity of the esterifying mechanisms for these substrates
(7) and 2) the presence of intracellular lipolytic systems. Evidence of the presence of intestinal lipases has been presented by a number of investigators. A monoglyceride lipase can be demonstrated in intestinal epithelial subcellular fragments $(13,20,21)$, particularly in the microsomes; this activity is not altered by washing the particles to remove traces of pancreatic lipase (13). Since the absorption of intact monoglyceride molecules has been demonstrated in experiments with doubly-labeled lipid $(22,23)$, the mucosal cells normally contain substrates upon which the monoglyceride lipase can act.

On the other hand, there is no good evidence that the usual dietary triglycerides (containing long chain fatty acids) can be absorbed unhydrolyzed. The physiological role, therefore, of the intracellular lipases demonstrated by some investigators to act on long chain triglycerides is unclear (24). In these previous studies contamination of tissue preparations by the highly active pancreatic lipase that bathes the mucosa was not always excluded. Also, some lipase estimations were performed at an alkaline $\mathrm{pH}$ using turbidimetric methods and synthetic detergents. In the present lipase experiments we attempted to avoid these possible sources of error. Lipolytic activity was estimated directly by measuring the amount of fatty acid liberated from a radioactive triglyceride substrate. Incubations were performed close to the physiological $\mathrm{pH}$ range and with taurocholate and albumin rather than with synthetic detergents.

The hydrolysis of trioctanoin observed in the present experiments appears not to have been due to contamination by pancreatic lipase for the following reasons: 1 ) the highest specific activity of the lipase acting upon trioctanoin was in the microsomal rather than the soluble fraction and was not influenced by repeated washing; 2) the substrate specificity of this lipase was different from that of pancreatic lipase; and 3) properties of the two enzyme systems, such as heat inactivation and inhibition by fluoride ions and sulfhydryl agents, readily distinguished between them (Table IV).

Esterification of octanoic acid by cell-free intestinal homogenates has previously been reported from this laboratory to be much less active than esterification of palmitic acid (7). Appar- 
ently the small quantity of trioctanoin that may be synthesized within the cell can be readily hydrolyzed by the enzyme system we have demonstrated. The highest specific activity of the lipase that hydrolyzes trioctanoin was in the microsomal fraction, which is the same cellular fraction involved in the majority of the reactions leading to intestinal triglyceride synthesis. Significantly, when $\mathrm{C}^{14}$-octanoic acid is incubated with hamster intestinal slices (25) and with rat everted gut sacs (26), there is very little incorporation of the label into glyceride esters. These findings probably reflect both the low rate of esterification of the free acid and rapid lipolysis of any trioctanoin synthesized. During the absorption of trioctanoin in the intact animal, these same two mechanisms would favor the presence of unesterified octanoic acid in the mucosal cells and its transport in the portal blood as discussed above.

To date, no attempt has been made to determine if the lipase that hydrolyzes trioctanoin is distinct from other mucosal lipases or esterases $(13,24,27)$. Trioctanoin was the only medium chain triglyceride used in our experiments. Further studies are needed to determine if the microsomal enzyme that splits trioctanoin is also active in the hydrolysis of other medium chain triglycerides as well as mono- and diglycerides. This might be anticipated because these substrates have similar physical and chemical properties (19).

The physical characteristics of the medium chain triglycerides, particularly their solubility and diffusibility when compared with triglycerides of higher molecular weights, suggested the possibility that transfer from intestinal lumen to mucosal cells might occur without prior lipolysis. In the anesthetized rat, trioctanoin was readily and rapidly absorbed by an isolated loop of small intestine despite the apparent absence of pancreatic lipase. The experimental evidence favored the entrance of the unhydrolyzed triglyceride into the mucosa and its subsequent intracellular hydrolysis and transport as unesterified fatty acid in the portal blood. It could be argued that the trioctanoin might have been hydrolyzed during its passage through the cell membrane by an enzyme located in the microvilli or brush borders of the mucosa. This possibility seems unlikely in view of the low lipolytic activity demonstrated in brush border preparations in vitro. In our experiments, furthermore, the trioctanoin was introduced as a suspension in albumin. Since bile salts had been surgically excluded from the lumen and no monoglyceride was added, the question of absorption of the trioctanoin from a micellar solution did not arise.

In normal circumstances the presence of pancreatic lipase ensures the extensive lipolysis of trioctanoin before its absorption, so that quantitatively the transport of the intact triglyceride is of limited significance. Patients with impaired fat absorption due to pancreatic or bile salt deficiency have, however, been reported to absorb medium chain triglycerides more completely than the usual dietary fats $(28,29)$. A similar trend has been noted in absorptive studies on children with fibrocystic disease of the pancreas $(4,5)$. It is reasonable to speculate that, although possibly unimportant in the normal subject, the direct adsorption of medium chain triglycerides and their subsequent intracellular hydrolysis may become an important consideration in the therapeutic approach to patients with impaired intraluminal digestion of fat.

\section{Summary}

1. Extensive lipolysis of $\mathrm{C}^{14}$-trioctanoin was observed when it was incubated with subcellular fractions of rat intestinal mucosa. The specific activity of the enzyme system that splits trioctanoin was greatest in the microsomal fraction. Tripalmitin, a long chain triglyceride, was not hydrolyzed by this microsomal enzyme system.

2. The lipase that hydrolyzes trioctanoin was found to be distinct from pancreatic lipase. . The substrate specificities of the two enzyme systems are dissimilar, and there are marked differences in the effects of heating, fluoride ions, and $p$ chloromercuribenzoate.

3. In vivo experiments using isolated loops of rat intestine indicate that $\mathrm{C}^{\mathbf{1 4}}$-trioctanoin can enter the mucosal cells without prior hydrolysis in the lumen. The demonstration of radioactive fatty acids in the intestinal mucosa and portal vein plasma suggests that the triglyceride was hydrolyzed within the mucosal cells. Under the same experimental conditions $\mathrm{C}^{14}$-tripalmitin was only poorly absorbed.

4. We postulate that a mucosal lipase such as that which acts on trioctanoin may have a role 
in the hydrolysis of medium chain triglycerides that are either ingested or synthesized within the intestinal cell. Furthermore, such an enzyme system by keeping medium chain fatty acids within the mucosa in the free, unesterified form may seem to favor their portal rather than lymphatic route of transport.

\section{Acknowledgments}

The authors are indebted to Miss Dorothy Budz and Mrs. Marilyn Kozacko for valuable technical assistance.

\section{References}

1. Bloom, B., I. L. Chaikoff, and W. O. Reinhardt. Intestinal lymph as pathway for transport of absorbed fatty acids of different chain lengths. Amer. J. Physiol. 1951, 166, 451.

2. Kiyasu, J. Y., B. Bloom, and I. L. Chaikoff. The portal transport of absorbed fatty acids. J. biol. Chem. 1952, 199, 415.

3. Borgström, B. Transport of ${ }^{14} \mathrm{C}$-decanoic acid in porta and inferior vena cava blood during absorption in the rat. Acta physiol. scand. 1955, 34, 71.

4. Van de Kamer, J. H., and H. A. Weijers. Malabsorption syndrome. Fed. Proc. 1961, 20 (suppl. 7), 335.

5. Fernandes, J., J. H. van de Kamer, and H. A Weijers. Differences in absorption of the various fatty acids studied in children with steatorrhea. J. clin. Invest. 1962, 41, 488.

6. Borgström, B. in Lipide Metabolism, K. Bloch, Ed. New York, John Wiley and Sons, 1960, p. 138.

7. Dawson, A. M., and K. J. Isselbacher. The esterification of palmitate-1-C $\mathrm{C}^{\mathbf{1 4}}$ by homogenates of intestinal mucosa. J. clin. Invest. 1960, 39, 150.

8. Norman, A. Preparation of conjugated bile salts using mixed carboxylic acid anhydrides. Arkiv Kemi 1955, 8, 331.

9. Senior, J. R., and K. J. Isselbacher. Direct esterification of monoglycerides with palmityl coenzyme A by intestinal epithelial subcellular fractions. J. biol. Chem. 1962, 237, 1454.

10. Miller, D., and R. K. Crane. The digestive function of the epithelium of the small intestine. II. Localization of disaccharide hydrolysis in the isolated brush border portion of intestinal epithelial cells. Biochim. biophys. Acta (Amst.) 1961, 52, 293.

11. Cohen, P. P. Methods for preparation and study of tissues in Manometric Techniques, W. W. Umbreit, R. H. Burris, and J. F. Stauffer, Eds. Minneapolis, Burgess, 1959, p. 149.

12. Folch, J., M. Lees, and G. H. Sloane Stanley. A simple method for the isolation and purification of total lipides from animal tissues. J. biol. Chem. 1957, 226, 497.

13. Senior, J. R., and K. J. Isselbacher. Demonstration of an intestinal monoglyceride lipase: an enzyme with a possible role in the intracellular completion of fat digestion. J. clin. Invest. 1963, 42, 187.

14. Dawson, A. M., and K. J. Isselbacher. Studies on lipid metabolism in the small intestine with observations on the role of bile salts. J. clin. Invest. 1960, 39, 730.

15. Playoust, M. R., and K. J. Isselbacher. Unpublished observations.

16. Blomstrand, R., N. A. Thorn, and E. H. Ahrens, Jr. The absorption of fats, studied in a patient with chyluria. I. Clinical investigation. Amer. J. Med. 1958, 24, 958.

17. Fernandes, J., J. H. van de Kamer, and H. A. Weijers. The absorption of fats studied in a child with chylothorax. J. clin. Invest. 1955, 34, 1026.

18. Palay, S. L., and L. J. Karlin. An electron microscopic study of intestinal villus. II. The pathway of fat absorption. J. biophys. biochem. Cytol. 1959, 5, 373.

19. Deuel, H. J., Jr. The Lipids. New York, Interscience Publishers, 1951, vol. 1, p. 57.

20. Tidwell, H. C., and J. M. Johnston. An in vitro study of glyceride absorption. Arch. Biochem. 1960, 89, 79.

21. Pope, J. L., R. E. Askins, and J. C. McPherson. The specificity of an intestinal lipase for monoglycerides. Fed. Proc. 1962, 21, 259.

22. Skipski, V. P., M. G. Morehouse, and H. J. Deuel, $\mathrm{Jr}$. The absorption in the rat of a 1,3-dioleyl-2deuteriostearyl glyceride- $\mathrm{C}^{\mathbf{1 4}}$ and a 1-monodeuteriostearyl glyceride-C ${ }^{14}$. Arch. Biochem. 1959, 81, 93.

23. Johnston, J. M., and J. L. Brown. The intestinal utilization of doubly-labeled $\alpha$-monopalmitin. Biochim. biophys. Acta (Amst.) 1962, 59, 500.

24. DiNella, R. R., H. C. Meng, and C. R. Park. Properties of intestinal lipase. J. biol. Chem. 1960, 235, 3076.

25. Gelb, A. M., and J. I. Kessler. Effect of fatty acid structure on esterification by the small intestine in vitro. Amer. J. Physiol. 1963, 204, 821.

26. Playoust, M. R., and K. J. Isselbacher. Unpublished observations.

27. Aldridge, W. N. Some esterases of the rat. Biochem. J. 1954, 57, 692.

28. Hashim, S. A., H. B. Roholt, and T. B. Van Itallie. Pancreatogenous steatorrhea treated with medium chain triglyceride. Clin. Res. 1962, 10, 394.

29. Iber, F. L., E. Hardoon, and M. H. Sprague. Use of eight and ten carbon fatty acids as neutral fat in the management of steatorrhea (abstract). Clin. Res. 1963, 11, 185. 